\title{
The Correlation Between Conscientiousness, Vocabulary Mastery, and Reading Achievement
}

\author{
Resa Indri Noor Andhiyanti, Muh. Asrori and Gunarso Susilohadi \\ English Education Department \\ Teacher Training and Education Faculty \\ Sebelas Maret University \\ Email: ressamulyono@ymail.com
}

\begin{abstract}
The literature says that there is correlation between conscientiousness and vocabulary mastery toward reading achievement. The objective of this article is to report the result of a correlational study between conscientiousness and vocabulary mastery toward reading achievement. This research used a correlation method. The population was the tenth grade students of SMAN 3 Boyolali in the academic year of 2013/2014. Class X-4 was taken as the sample by using cluster random sampling. The data were obtained by means of questionnaire and tests. The data were analysed by single correlation, multiple linear regression and multiple correlation. The findings shows that there a positive correlation between conscientiousness, students' vocabulary mastery toward students' reading achievement, both partially and simultaneously. The positive correlation indicated that the increase of students' conscientiousness and vocabulary mastery will be followed by the increase of the students' reading achievement.
\end{abstract}

Keywords: conscientiousness, vocabulary mastery, reading achievement

\begin{abstract}
ABSTRAK
Literatur mengatakan bahwa ada korelasi antara sifat-berhati-hati dan penguasaan kosakata terhadap prestasi membaca. Tujuan artikel ini adalah untuk melaporkan hasil dari studi korelasi antara sifat berhati-hati dan penguasaan kosakata terhadap prestasi membaca. Penelitian ini menggunakan metode korelasi. Populasi dari penelitian ini adalah kelas sepuluh SMAN 3 Boyolali tahun ajaran 2013/2014. Kelas X-4 diambil sebagai sampel dengan menggunakan sampling acak kelompok. Data diperoleh dengan menggunakan kuesioner dan tes. Data dianalisis dengan menggunakan hubungan tunggal, regresi linear ganda dan hubungan ganda. Hasil penelitian menunjukkan bahwa terdapat hubungan positif antara sifat berhati-hati, penguasaan kosakata siswa terhadap prestasi membaca siswa, baik secara terpisah maupun bersamaan. Korelasi positif ini mengindikasikan bahwa peningkatan sifat hati-hati siswa dan penguasaan kosakata akan diikuti oleh peningkatan prestasi membaca siswa.
\end{abstract}

Kata Kunci: sifat hati-hati, penguasaan kosakata, prestasi membaca 
In countries around the world, some school systems require students to learn English based on reading skill first before speaking, writing and listening. English Language Learners knowledge are broadened and enhanced by reading activity. Teachers believe that reading skill is the basic skill in English learning. Successful reading activity can be achieved by bringing some factors which help readers to extract the information from a written text. Learners who know any vocabulary of a language and have high motivation to reach the goal will get better performance in reading achievement. Thus, pre-teaching vocabulary and utilising learners' motivation toward learning can give virtue to their reading achievement.

According to Grabe (2009, p. 6), reading English texts provide a highway for learner to develop their English language abilities in order to achieve the academic curricular goals. Therefore, it cannot be denied that having reading skills in learning English as second or foreign language is needed for English learners to get better performance in the learning process. Learners must read a lot of written text types and make that activity as a habit.

Urquhart and Weir (1998, p. 22) say that reading process is an activity of receiving and interpreting information encoded in written language. This activity includes the process of comprehending and assigning the meaning of the written text. Nuttall (1996, p. 4) argues that reading is a process of transferring a message from the writer through the text to the reader as a communication. Nation (2008, p. 59) reveals that reading activity involves the goal of understanding the text and learning language items from the text. Grellet (1981, p. 8) defines reading as an 
active skill that constantly involves activities of guessing, predicting, checking and asking about the information of a text.

Thus, reading achievement in this research means a level of competence in area of reading skill; where reading is a communication process between the reader and the text to comprehend the meaning from medium of print. It involves activities of guessing, predicting, checking and asking ideas or information in the text.

English learners should be able to comprehend a written text when they are reading. As stated by Burns and his colleagues (1984, p.151), basic comprehension unit in reading are words, sentences and paragraphs. In the reading process, the readers are demanded to know the meaning of the words in the text to better understand about the content because words are the smallest unit of a text. Therefore, vocabulary takes important role as a linguistic aspect of language which influences readers in assigning meaning from a text that they read. According to Nunan, development of rich vocabulary is importantly needed in second language acquisition (1991, p. 118). While, Aebersold and Field (1997, p. 139) say that words appear in the written text because they convey the topic of that text.

Hatch and Brown $(1995$, p. 1) state that vocabulary contains a words list of particular language that learners of language might use. Hornby (2003, p. 483) defines vocabulary as: (1) all the words that a person knows or uses, (2) all the words in a language, and (3) a list of word with their meaning. Burns and Broman (1975, p. 295) say that vocabulary may be defined as the total number of 
words (with its meaning) which are used by person, class or profession to make up language either in oral or written communication.

Thus, vocabulary mastery in this research is defined as a complete knowledge of word properties in particular language with the words meaning. This words knowledge includes knowing its form (spelling, pronunciation, and word formation), meaning (relation of words), and use (collocation and grammar).

Another factor which is contributed toward reading activity is conscientiousness characteristic. This characteristic has a role as learners' intrinsic motivation. Bligh (2009, p. 639) defines Conscientiousness “as an individual's tendency to be organized, thorough, controlled, decisive and dependable”. Maltby and his colleagues (2010, p. 172) say that conscientiousness describes the degree of self-discipline and control. Godlberg (in Ali and Bano, 2012, p. 260) explains that conscientiousness as characteristics which drive individual to achieve something and contain such characteristics of being organized, systematic, efficient, practical and steady. In line with that, McCrae and Costa (2006, p. 50) reveal conscientious people consider that they are high in competence, selfdiscipline, achievement striving and pursuing excellence in everything they do. They are also characterized by deliberation, making plans in advance and thinking carefully before acting. It means that conscientiousness is individual's characteristics in terms of self-discipline, achievement-striving, motivation to pursue the goal, and deliberation.

According to Brown (in Simanjuntak, 1988, p. 12), no successful cognitive or affective activity can be carried out without degree of self-confidence, self- 
knowledge, and belief in own capabilities for that activity. He believes that personality characteristics contribute in some ways to the success of reading fluency. Personality takes role to choose the suitable learning style in the process of achieving the learning language goal. It motivates students to learn in their own way. Conscientiousness which is discussed in this research is defined as characteristics of individual in term of competence, order, dutifulness, achievement striving, self-discipline, and deliberation.

According to the previous theories, conscientiousness and vocabulary mastery contribute to the successful of reading achievement. The aim of this article is to report the result of a correlational study between conscientiousness and vocabulary mastery toward reading achievement, both partially and simultaneously.

\section{RESEARCH METHOD}

The method which is used in this research is a correlational method. Fraenkel and his colleagues (2011, p. 10) define correlational method as "a method which is to clarify our understanding of important phenomena by identifying relationships among variables". They also state that the goal of correlational research is to determine whether a relationship exists between two (or more) quantitative variables. Therefore, the objective of this research is to empirically prove that there is a correlation between conscientiousness between conscientiousness and vocabulary mastery toward reading achievement, both partially and simultaneously. 
This research was carried out at SMA Negeri 3 Boyolali in June 2014. The population of this research is the tenth grade students of SMA Negeri 3 Boyolali in the academic year 2013/2014. The sample of the research was taken by cluster random sampling technique and Class $\mathrm{X}-4$ is chosen as the sample of this research. There were 32 students, however, only 28 students took the test.

The instruments which are used to collect the data of this research are questionnaire and tests. A questionnaire which consists of 35 items was used to assess the level of conscientiousness of students and multiple-choice tests were used to assess the students' vocabulary mastery and students' reading achievement. There are 27 items for vocabulary mastery test and 40 items for reading achievement test.

The questionnaire used was a ready-made questionnaire retrieved from the L. R. Goldberg's official website of personality measurement (http://ipip.ori.org) with free translation and development by the writer. The questionnaire type is a close-type questionnaire. According to Arikunto (2006, p. 152), close-type questionnaire is the questionnaire in which the answers of the questionnaire provided, so the respondents only have to choose the suitable answer. In this research the answers are divided into 5 choices, they are: Strongly Agree, Agree, Less Agree, Disagree, and Strongly Disagree.

It is needed to conduct try-out for the research instrument before it is used to take the data of the sample. Try-out is used to know the validity and reliability of the instrument since good instruments have to be valid and reliable. The try-out 
test was done by class X-3 of the Tenth Grade Students of SMAN 3 Boyolali in the academic year 2013/2014.

The data are analysed by using Product Moment Formula and Multiple Linear Regression Formula. Product Moment Formula is used to find out the correlation between two variables (single correlation), while, Multiple Linear Regression is used to find out the correlation between several independent variables and one dependent variable (multiple correlation).

\section{RESEARCH FINDINGS AND DISCUSSIONS}

Correlation analysis shows a significant relationship between conscientiousness, vocabulary mastery and reading achievement. The first hypothesis which says that there is a positive correlation between conscientiousness and reading achievement is accepted. The result of the single correlation computation of $\mathrm{X}_{1}$ and $\mathrm{Y}$ shows that the value of the correlation coefficient $\left(\mathrm{r}_{\mathrm{x} 1 \mathrm{y}}\right)$ is 0.3967 . Its value is consulted to $\mathrm{r}$-table at the significance level $\alpha=0.05$ for $\mathrm{n}=28(0.374)$ and shows that $\mathrm{r}_{\mathrm{x} 1 \mathrm{y}}(0.3967)$ is higher that $\mathrm{r}_{\mathrm{t}}(0.374)$ or $r_{x 1 y}(0.3967)>r_{t}(0.374)$. From those computation shows that the value of distribution $t_{o b t a i n e d}$ is 2.2036 and it is consulted to $t_{\text {table }}(1.70)$. Because $t_{o}(2.2036)$ is higher than $t_{t}(1.70)$ or $t_{o}(2.2036)>t_{t}(1.70)$, the value of the coefficient correlation (r) is significant. The coefficient determination $\left(r^{2}\right)$ between conscientiousness and reading achievement is 0.1574 . It means $15.74 \%$ variance of reading achievement is determined by conscientiousness and $84.26 \%$ variance of reading achievement is determined by other factors. 
Thus, characteristics of the conscientiousness give contribution to motivate learners in language learning through reading activity. Learners who have high self-discipline, self-control and achievement-oriented are more motivated to learn through reading. They believe that through reading activity can enhance their knowledge and extend their language ability during language learning process. Komarraju and his colleagues (2009, p. 49) say that conscientious learners tend to be more discipline, organized, and achievement-oriented and it would be positively related to intrinsic motivation and achievement performance.

The research which is conducted by Komarraju and his colleagues (2009) report that conscientiousness has a significant relationship with the higher scores in academic motivation and achievement. They find that conscientiousness provides strong contribution in explaining academic motivation and achievement. It appears as the central of academic motivation, suggesting that learners who are disciplined and organized are most likely to be motivated toward learning. Komarraju and Karau (2005) in their study also prove that achievement motivation (persisting and competing) was best explained by conscientiousness, neuroticism and openness. Their study find that conscientiousness supports a significant consequence on the learners' motivation and their reading achievement.

Other research, Ali and Bano (2012) found that conscientiousness has higher positive correlation toward reading skill than the other big-five personality traits; openness, extraversion, agreeableness and neuroticism. While, Noftle and 
Robin (2007) report that conscientiousness is the stronger predictor of academic performance which is explained by high school GPA.

Furthermore, the second hypothesis which says that there is a positive correlation between vocabulary mastery and reading achievement is accepted. The result of the single correlation computation of $\mathrm{X}_{2}$ and $\mathrm{Y}$ shows that the value of the correlation coefficient $\left(\mathrm{r}_{\mathrm{x} 1 \mathrm{y}}\right)$ is 0.569 . Its value is consulted to r-table at the significance level $\alpha=0.05$ for $\mathrm{n}=28(0.374)$ and shows that $\mathrm{r}_{\mathrm{x} 1 \mathrm{y}}(0.569)$ is higher that $r_{t}(0.374)$ or $r_{x 1 y}(0.569)>r_{t}(0.374)$. Those computation shows that the value of distribution $t_{\text {obtained }}$ is 3.5279 and it is consulted to $t_{\text {table }}(1.70)$. Because $t_{o}$ (3.5279) is higher than $t_{t}(1.70)$ or $t_{o}(3.5279)>t_{t}(1.70)$, the value of the coefficient correlation (r) is significant. The coefficient determination $\left(\mathrm{r}^{2}\right)$ between vocabulary mastery and reading achievement is 0.3237 . It means $32.37 \%$ variance of reading achievement is determined by vocabulary mastery and $67.63 \%$ variance of reading achievement is determined by other factors.

The result shows that vocabulary mastery improves learner' reading achievement. Learners who have knowledge about vocabulary of a language will have good comprehension ability in reading activity. As are stated by Burns and his colleagues (1984, p.151), basic comprehension units in reading are words, sentences and paragraphs. Therefore, learners can comprehend an English text if they have knowledge of vocabulary on English. It can be stated that English learners will get successful reading activity when they grasp any information from written text they read. Koda (2004) supports the research's result, he says that 
success in comprehending a text depends on the reader's knowledge of individual's word meaning.

The result of this research are in line with a description by Wessels (2011). She describes that there is four characteristics of the important vocabulary in order to be successful in reading process, those are: (1) accessing background knowledge, (2) connecting unknown vocabulary to known knowledge, (3) ensuring opportunities for meaningful use of the vocabulary words and (4) providing multiple exposures. Thus, this research is proving the role of the vocabulary acquisition in reading achievement.

Concisely, vocabulary mastery has been proved as a crucial component in contribution toward reading achievement. It means that English learners' acquisition of vocabulary is important to the success of reading activity. Therefore, it is beneficial to put more focus on pre-teaching vocabulary in the pedagogical environment to improve English learners' ability in all aspects of learning. Considering the aim of reading for enhancing learners' knowledge and perception on language learning, teaching vocabulary before learners begin to read will help them to make it easier to predict the meaning of the English text. It is also stimulating their background knowledge before reading by providing vocabulary background.

The third hypothesis says that there is a positive correlation between conscientiousness and vocabulary mastery toward reading achievement. That hypothesis is accepted, because the result shows that the value of coefficient of multiple correlation $(\mathrm{R})$ is 0.657 . While, the significance testing of this coefficient 
in $F_{\text {observation }}$ is 9.51 . The value of $F_{o}$ is consulted to F-table at the significance level $\alpha=0.05$ and the degree of freedom (d.f.) for 2.25 is 3.39 . It shows the value of $F_{o}(9.51)$ is higher than $F_{t}(3.39)$ or $F_{o}(9.51)>F_{t}(3.39)$, so, it can be concluded that coefficient of multiple correlation $(\mathrm{R})$ is significant. The value of coefficient determination $\left(\mathrm{R}^{2}\right)$ is 0.4321 . It means that $43.21 \%$ variance reading achievement is determined by conscientiousness and vocabulary mastery, and the rest $56.79 \%$ variance of reading achievement is determined by other factors.

From this result, it is found that there is a significant and positive correlation between conscientiousness and vocabulary mastery simultaneously toward reading achievement of the tenth grade students of SMA Negeri 3 Boyolali in the academic year of 2013/2014. It means that the increase of conscientiousness and vocabulary mastery will be followed by the increase of reading achievement.

Conscientiousness plays role to motivate learners toward learning process. It contains characteristics of high in self-discipline and self-control, dutifulness and achievement oriented. In some ways, conscientious learners have better performance in achieving the goal of learning. They are also interested in how to achieve the level of competence and scrupulous on the precepts which drive to the goal of learning. Conscientious learners tend to pursue the achievement goal in learning process through reading activity. Miller (1972) says that reading activity is important for conscientious students who are engaged in the search of many knowledge concepts in education area. It is also supported by Hedgcock and Ferris $(2009$, p. 56). They argue that "reading is an important aspect of long term 
language development". Thus, learners who have high in conscientiousness are likely to be motivated to read.

Wilkins (in Thornburry, 2002, p. 13) notes, "Without grammar very little can be conveyed, without vocabulary nothing can be conveyed". It means that if English learners do not have knowledge about vocabulary when they begin to read, they could not get any information during reading process. This might happen because they find some unknown vocabulary of a language and they do not know those meanings. So, it is impossible for English learners to comprehend a written text without any vocabulary knowledge. Thus, the numbers of vocabulary can determine students' reading achievement.

Based on the explanation above, it can be concluded that conscientiousness is related to reading achievement as an intrinsic motivation factor. While, reading activity as a process of language development needs readers' vocabulary acquisition, so, Learners who have an acquisition in vocabulary will be able to comprehend the meaning which is conveyed in the written text. Hence, learners' vocabulary mastery influences their reading achievement; more numbers of vocabularies that readers know will help them to better comprehend a written text.

\section{CONCLUSIONS AND SUGGESTIONS}

From this research, some conclusions can be drawn. First, conscientiousness has a positive correlation and contribution toward students' reading achievement. Second, students' vocabulary mastery also has a positive 
correlation and contribution toward their reading achievement. Third, conscientiousness and vocabulary mastery simultaneously, have a positive correlation and contribution toward reading achievement.

Furthermore, as the implication of the research, conscientiousness and vocabulary mastery can be used to improve students' reading achievement. Nowadays, there are many issues that teachers need to consider when they teach language learners. They could not only focus on the curriculum system but also need to concern toward learners' personality in order to reach the goal of learning process. Teachers could create learning environment and choose the best method considering the learners' motivation in teaching and learning process. Learners are hoped to learn more vocabulary before they begin to read, because it helps them to predict and guess the information in the text.

\section{REFERENCES}

Aebersold, Jo Ann \& Field, Mary Lee. (1997). From Reader to Reading Teacher. Cambridge: Cambridge University Press

Ali, DilshadAkber., \&Bano, Dislhat. (2012). Personality Types \& Reading: a Correlational Research. Interdisciplinary Journal of Contemporary Research in Business, Volume 4(3), 254-269. Retrieved from http://ijcrb.webs.com

Arikunto, Suharsimi. (2006). Prosedur Penelitian Suatu Pendekatan Praktik. Jakarta: PT Asdi Mahasatya

Bligh, Michelle C. (2009). Personality Theories of Leadership. Encyclopedia of Group Processes \& Intergroup Relations, 639-642. Published at April, 8 2011

Burns, Paul C., \& Broman, Betty. (1975).The Language Arts in Childhood Education. Chicago: Rand McNally 
Burns, Paul C., Roe, Michael H., \& Ross, James R. (1984). Teaching Reading in today's Elementary Schools. Massachusetts: Houghton Mifflin Company

Fraenkel, J. R., \& Wallen, N. E. (2000). How to Design \& Evaluate Research in Education $\left(4^{\text {th }} e d\right)$. New York: McGrew-Hill Companies, Inc

Grabe, William. (2009). Reading in a Second Language. New York: Cambridge

Grellet, Francoise. (1981). Developing Reading Skills. Cambridge: Cambridge University Press

Hatch, Evelyn \& Brown, Cheryl. (1995). Vocabulary, Semantics \& Language Education. Cambridge: Cambridge University Press

Hedgcock, John S., \& Ferris, Dona R. (2009). Teaching Readers of English. New York: Routledge

Hornby, A. S. (2003). Oxford Advanced Learner's Dictionary. Oxford: Oxford University Press

Koda, K. (2004). Insights into Second Language Reading: a cross-linguistic approach. Cambridge: Cambridge University Press

Komarraju, M., \& Karau, S. J. (2005). The relationship between the Big Five Personality Traits and Academic Motivation. Personality and Individual Differences, volume 39, 557-567

Komarraju, Meera., Karau, Steven J., \& Schmeck, Ronald R. (2008). Role of the Big Five Personality traits in predicting college students' academic motivation \& achievement. Learning \& Individual Differences, Volume 19, (2009), 47-52. doi: 10.1016/j.lindif.2008.07.001

Maltby, John., Day, Liz., \& Macaskill, Ann. (2010). Personality, Individual Differences \& Intelligence ( $2^{\text {nd }}$ eds). Harlow: Pearson

McCrae, Robert R. \& Costa, Paul. T. Jr. (2006). Personality in Adulthood: a five factor theory perspective ( $2^{\text {nd }}$ eds). New York: Guilford Press

Miller, Lyle L. (1972). Developing Reading Efficiency. Minnesota: Burgess Publishing Company Nation, I. S. P. (2008). Teaching Vocabulary. Boston: Heinle and Heinle

Noftle, E.E., \& Robins, R.W. (2007). Personality Predictors of academic outcomes: Big five correlates of GPA and SAT scores. Journal of Personality and Social Psychology volume 93, 116-130

Nunan, David. (1991). Language Teaching Methodology. London: Practice Hall

Nuttall, Christine. (1996). Teaching Reading Skills in a foreign language. Oxford: Heinemann 
Simanjuntak, Edithia Gloria. (1988). Developing Reading Skill for EFL Students. Jakarta: Departemen Pendidikan dan Kebudayaan

Thornburry, Scott. (2002). How to Teach Vocabulary. Harlow: Pearson

Urquhart, S., \&Weir, C. (1998). Reading in a Second Language: Process, Product \& Practice. New York: Longman

Wessel, Stephanie. (2011). Promoting Vocabulary learning for English Learners. The Reading Teacher, volume 65 (1), 46-50. International Reading Association 